\title{
The Effectiveness of Village Consultative Body in Kuningan District in Implementing Legislative Function
}

\author{
Erga Yuhandra and Gios Adhyaksa \\ Faculty of Law , University of Kuningan, Indonesia \\ E-mail : ergayuhandra@gmail.com
}
How to cite : Yuhandra, Erga; Gios Adhyaksa. (2018). The Effectiveness of Village Consultative Body in Kuningan District in Implementing Legislative Funcition . UNIFIKASI : Jurnal Ilmu Hukum, 5(2), 106- 111. DOI : $10.25134 /$ unifikasi.v5i2.922

Submitted : 04-04-2018 Revised : 30-08-2018 Accepted : 09-09-2018

\begin{abstract}
Village Government has a very significant role in managing social processes in the society. The purpose of this research is to examine the process of village regulations making in Kuningan District and the effectiveness of the Village Consultative Body (BPD) in implementing legislative function. The method used in this research was a juridical-empirical research method. A rational analysis based on juridical references was then conducted through literature and field research. The results showed that the Village Consultative Body as a legislative institution at the lower level has an important role in establishing government legal products to realize checks and balances system and accommodating the society's aspirations. Normatively, the establishment of village regulations in Sukaharja village is not running properly, and in its implementation, the establishment of village regulation in Sukaharja has not fully contained the principles of good regulations making based on Law Number 12 of 2011 concerning Establishment of Legislation. In its process, there are some stages which are not implemented by both village head and BPD so that the regulation is less effective for the society. The Village Consultative Body has three main functions, namely legislation, supervision, and aspiration. Here, the Village Consultative Body is still less effective in implementing those three functions, especially the legislative function. It can be seen from the period of 2010-2015 in which the legal products produced by the BPD are very low, whereas there are many provisions that should have a legal umbrella in order to create legal certainty for the society. This situation happens because there is a lack of human resources in forming the village regulation draft, and the village government does not understand what the contents of the village regulations that should have a legal umbrella in village regulations making.
\end{abstract}

Keywords: Village Consultative Body, Authority, Legislation

\section{Efektivitas Badan Permusyawaratan Desa di Kabupaten Kuningan dalam Menjalankan Fungsi Legislasi}

\begin{abstract}
Abstrak : Pemerintah Desa memiliki peran yang sangat signifikan dalam pengelolaan proses sosial di dalam masyarakat. Tujuan penelitian ini adalah untuk mengetahui dan mengkaji bagaimana proses pembentukan peraturan desa di Kabupaten Kuningan dan evektifitas Badan Permusyawaratan Desa dalam menjalankan fungsi legislasi. Metode penelitian yang digunakan dalam penelitian ini adalah metode penelitian yuridis-empiris selanjutnya dilakukan analisa rasional berdasarkan acuan yuridis melalui penelitian kepustakaan dan lapangan. Hasil penelitian bahwa Badan Permusyawaratan Desa merupakan lembaga legislatif di tingkat bawah yang mana memiliki peranan penting dalam pembentukan produk hukum pemerintahan desa untuk mewujudkan sistem $c h e c k$ and balences dan penyambung lidah masyarakat dalam menyampaikan aspirasi. Secara normatif pembentukan perdes di desa Sukaharja belum sesuai, namun dalam tarap implementasinya dalam pembentukan peraturan desa di desa Sukaharja belum sepenuhnya memuat asas-asas pembentukan peraturan yang baik menurut UndangUndang Nomor 12 Tahun 2011 tentang Pembentukan Peraturan Perundang-undangan. Dalam prosesnya masih terdapat tahapan-tahapan yang tidak dijalankan baik oleh kepala desa maupun BPD, sehingga peraturan tersebut kurang berdaya guna bagi masyarakat. Badan Permusyawaratan Desa memiliki tiga fungsi yaitu legislasi, pengawasan, dan menampung aspirasi masyarakat. Dalam menjalankan fungsi legislasi tertutama dalam hal ini masih kurang efektif dilihat dari kurun waktu tahun 2010-2015 produk hukum yang dihasilkan oleh BPD sangat rendah, seyogianya banyak ketentuan yang harus dibuatkan payung hukum agar terciptanya kepastian hukum bagi masyarakat setempat. Hal tersebut terjadi karena masih minimnya sumber daya manusia dalam menyusun draf rancangan perdes, serta pemerintah desa belum memahami apa saja materi muatan dari peraturan desa yang harus dibuat payung hukum dalam pembuatan perdes.
\end{abstract}

Kata Kunci: Badan Permusyawaratan Desa, Kewenangan, Legislasi 


\section{INTRODUCTION}

The legal area for the implementation of regional autonomy in Indonesia is based on Article 18 paragraph (1) of the 1945 Constitution of the Republic of Indonesia, as follows: "The Unitary State of the Republic of Indonesia is divided into provincial areas and the provincial areas are divided into districts and cities in which each province, district, and city has a regional government regulated by Act". ${ }^{1}$

By examining the history of the establishment of the 1945 Constitution, it can be said that Muh. Yamin was the first to discuss the issue of regional governance in the BPUPKI session on May 29, 1945. Muh. Yamin said: Country, Village, and all alliances of customary law are reformed through rationalism and development, made as the foot of the arrangement in the lower parts. Between the upper and lower parts, a central part is formed as a regional government to run the Internal Affairs Government, Pengrah Praja. ${ }^{2}$ During the Dutch East Indies period, village government was arranged differently between Java and outside Java. In Java, it is regulated in the Inlandsegemeente Ordonatie (IGO). Outside Java, it is regulated in the Inlandsegemeente Ordonatievoor Buiten Gewesten (IGOB).

These provisions only regulate village organizations because some village governments have been existed far before the regulation in IGO and IGOB. ${ }^{3}$ With the issuance of related legal products concerning regional governments that seem to be aware of the wrong approach contained in Law Number 5 of 1979, the village government was included as a unit in the Regional Government Act. Judging from the politics of government, including village government in the Regional Government Act has an important meaning. As a form of regional government, the village should get all status and position, along with

\footnotetext{
Jimly Asshiddiqie, 2009, Komentar Atas Undang-Undang Dasar Negara Republik Indonesia Tahun 1945, Sinar Grafika, Jakarta, pp. 57.

2 M. Yamin, 2012, Naskah Persiapan Undang-Undang Dasar 1945, Penerbit Siguntang, Jakarta, 1971, hlm. 100. Lihat juga Ni'matul Huda, Hukum Tata Negara Indonesia- Edisi Revisi, Rajawali Press, Jakarta, pp. 301.

Bagir Manan, 2005, Menyongsong Fajar Otonomi Daerah, Pusat Studi Hukum (PSH) Fakultas Hukum UII Yogyakarta, Yogyakarta, Cetakan IV, pp. 158.
}

various elements of regional government like provinces, districts, or cities. ${ }^{4}$

The Village Government has a very significant role in managing social processes in society. The main task that the Village Government should carry out is how to create a democratic life and provide good social services, so that it can bring a prosperous, peaceful, secure, and fair life to the society. ${ }^{5}$ The implementation of village governance is a subsystem of the governance system, so that the village has the authority to regulate and manage the society's interests. Villages can take legal actions in both public and private law, can possess property and buildings, and can prosecute and be prosecuted in court. For this reason, the village head with the approval of the Village Consultative Body has the authority to conduct legal actions and enter into mutually beneficial agreements. ${ }^{6}$

The role of BPD with its function and authority in discussing and establishing Village Regulation draft with the Village Head is a policy and legal framework for the administration of governance and village development. The establishment of village regulations is the elaboration of various authorities possessed by the village which is based on the needs and conditions of the village, as well as referring to the higher legislation. As a legal product, village regulations should be in line with higher regulations and should not harm the public interests. As a political product, village regulations are established democratically and in a participative way in which the process involves community participation. Here, the community has the right to propose or provide input to BPD and Village Head in the process of village regulations making. ${ }^{7}$

As a lower level legislative body, BPD should have the same ability as the legislative

Untuk menghindari salah pengertian, yang dimaksud memiliki status dan kedudukan seperti Provinsi, kabupaten, atau kota, adalah status dan kedudukan hukum. Ibid, pp. 159.

M. Firmanhadi, 2013, Hubungan Fungsional Antara Pemerintah Desa dengan BPD dalam Menjalankan Pelaksanaan Pemerintahan Desa Berdasarkan UndangUndang Nomor 32 Tahun 2004 tentang Pemerintahan Daerah, Jurnal Ilmiah Fakultas Hukum Universitas Mataram, pp. 1 .

6 Dirgantara Dani Putra, 2009, Hubungan dan Peran Serta Badan Permusyawaratan Desa (BPD) dan Pemerintahan Desa Dalam Penyelenggaraan Pemerintahan Desa, Skripsi Universitas Sebelas Maret Surakarta, Solo, pp. 4.

E.B. Sitorus, dkk, 2007, Naskah Akademik Rancangan Undang-Undang tentang Pemerintahan Desa, DEPDAGRI, Jakarta, pp. 7. 
body at the central level in implementing legislative function. Yet, it was found that many BPD are lack of effectiveness in implementing legislative function. Based on the background above, the main issues discussed in this research are as follows: How is the effectiveness of the Village Consultative Body in implementing legislative function in the period of 2010-2016? What is the process of village regulations making in Sukaharja village, Kuningan District in relation to Law Number 12 of 2011 concerning Establishment of Legislation?

\section{METHOD}

The method used in this research is a juridical-empirical research method or quantitative research. ${ }^{8}$

1. Primary data are data derived from observations and interviews toward informants who include local village government, members of the Village Consultative Body, community, local community leaders, and academicians.

2. Secondary data are in the form of legal books, legal materials, legal articles and journals, comments on court decisions, and legal works related to the research.

\section{RESULTS AND DISCUSSION}

The term "legislation" comes from English word which means (1) law and (2) law making. Meanwhile, the word "legislation" comes from the verb "to legislate" which means to regulate or to establish laws. In Indonesian Language Dictionary (KBBI), the word legislation means the legislator. Thus, the legislative function is a function of law making. ${ }^{9}$ As a function to establish laws, legislation is a process. Therefore, Woodrow Wilson in his book "Congressional Government" says that "legislation is an aggregate, not a simple production." In the same vein, Jeremy Bentham and Jhon Austin say that legislation is "any form of lawmaking." Thus, the form of regulations established by the legislative for general binding purposes can be related to the definition of "anacted law", "statute", or law in

\footnotetext{
H.M. Hadin Muhjad \& Nunuk Nuswardani, 2012, Penelitian Hukum Indonesia Kontemporer, Genta Publishing, Yogyakarta, pp. 22.

Saldi Isra, 2010, Pergeseran Fungsi Legislasi (Menguatnya Model Legislasi Parlementer Dalam Sistem Presidensial Indonesia, PT Rajagrafindo Persada, Jakarta, pp. 78.
}

the broadest sense. In that sense, the legislative function is a function of law making. ${ }^{10}$

Meanwhile, Jimly Asshiddiqie in his book "Introduction to Constitutional Law" says that legislative function involves four types of activities, namely; 1) legislative initiation, 2) law draft discussion (law making process), 3) law enactment approval, and 4) granting approval or ratification on international agreements and other binding legal documents. $^{11}$

Then, according to Miriam Budiardjo, legislative or legislature reflects one of its functions, namely legislate or law-making. Another name that is often used is assembly that prioritizes the element of "gathering" (to discuss public problems). Other name is parliament, a term emphasizing on the element of "talking" and "negotiating". The other one prioritizes the representation of its members and is called the People's Representative Body or the House of Representatives. However, whatever the name is, it can be ascertained that this body is a symbol of sovereign people. ${ }^{12}$

The Village Consultative Body, which is then referred to as BPD, is an institution as the realization of democracy ${ }^{13}$ in village governance. The concept of Village Consultative Body (BPD) which was previously referred to as Village Consultative Agency, Village Representative Body, until finally Village Consultative Body, is a policymaking body and a supervisor of village policy implementation. The Village Consultative Body is a realization of democracy in village. The democracy means that the implementation of governance and development should pay attention to the community aspirations that are articulated and accommodated by BPD and other community institutions.

In Article 29 of Government Regulation Number 72 of 2005, the Village Consultative Body has a role as an organizer of Village Governance in which its function is to establish village regulations together with the Village Head, and to accommodate and convey

\footnotetext{
Ibid, pp. 79

Jimly Asshiddiqie, 2011, Pengantar Ilmu Hukum Tata Negara, Rajawali Press, Jakarta, pp. 299.

12 Miriam Budiardjo, 2010, Dasar-Dasar Ilmu Politik, PT Gramedia Pustaka, Utama, Jakarta, pp. 315.

13 Siti Aminah dalam bukunya mengatakan bahwa desentralisasi dapat berarti kemajuan menuju perbaikan tata kelola dan demokrasi serta sebagai erosi kondisi kesejahteraan di tingkat lokal kesejahteraan. Lihat Siti Aminah, 2014, Kuasa Negara Pada Ranah Politik Lokal, Kencana, Jakarta, pp. 53.
} 
the aspirations of the community. Therefore, BPD as the Consultative Body originates from the village community itself. In addition to carrying out its function as a bridge between the village head and the community, BPD should also carry out its main function, namely representative function.

BPD membership, as stated in Article 30 of Government Regulation Number 72 of 2005 , is the representative of the relevant village population based on regional representation. BPD members consist of the chairperson of the community association, traditional stakeholders, professional groups, religious leaders, and other community leaders. The term of office for BPD members is 6 years and can be appointed/re-proposed for the next 1 term. BPD leaders and members are not allowed to concurrently serve as Village Heads and other Village positions.

\section{The Process of Village Regulations Making (Perdes)}

Sukaharja Village is a Village originating from Cibingbin Village as a Rural Village which is on the boundary of the eastern part of West Java Province bordering the West part of Central Java Province. The area of Cibingbin Village was 23,160.5 Ha consisting of several Blocks, including Pahing, Manis, Kaliwon, Pon, Wage, Dukuh Girang, and Dukuh Seureuh Block, with a population of 12.300 at that time.

In 1970, the Government Offices, both District Offices, KUA Offices and Koramil Offices including SD and MI, were in Cibingbin Village territory and located in Dukuh Seureh and Dukuh Girang Block. There was even $9392 \mathrm{M}^{2}$ of village land which had been built as settlements.

The large population of Cibingbin Village and the large size of the area caused a lot of village and community development was not coordinated. Therefore, there was a pressure from religious and community leaders, especially from Dukuh Seureuh Block and Dukuh Girang Block, to separate them from Cibingbin Village. Then, the two proposed blocks for this separation are Dukuh Seureuh Block and Dukuh Girang Block since their population has reached 2269 people, consisting of 1088 male and 1181 females.

On the basis of a strong will and desire, all criteria and requirements for the separation are always fulfilled along with the valid regulations. Then, on October 14, 1982, the
Decree of the Kuningan Head District Level II, Number 689/HK./021.1/SK/A/X/1982 concerning the Establishment of the Preparatory Village to become a village with the name of Sukaharja Village was issued.

The draft of village regulations is determined by the village head and BPD in the village government work plan. Community institutions, traditional institutions and other village institutions can provide input to the Village Head and/or BPD for village regulations draft.

The Village Consultative Body (BPD) can compile and propose a Village Regulations Draft, except village regulations relating to: ${ }^{14}$

1. Village Medium Term Development Plan;

2. Village Government Work Plan;

3. Village APB;

4. Accountability Report on the Realization of Village APB Implementation

The discussion on the village regulations draft conducted by the Village Consultative Body is as follows:

1. BPD invites the Village Head to discuss the village regulation draft;

2. If the Village Regulation draft is the initiative of the Village Government and the BPD's draft regarding the same thing and in the same discussion period, the BPD's draft takes precedence, while the Village Government's draft is used as a comparison material;

3. The Village Regulation draft that has been discussed cannot be withdrawn, except for a joint agreement between BPD and Village Government.

\section{The effectiveness of Village Consultative Body in implementing legislative function}

In accordance with the new legislation, the Village Consultative Body is one of the elements of Village Governance. This position is to strengthen the village government in carrying out its authority to regulate and manage its own household democratically in accordance with the community aspirations. In carrying out its duties, the Village Consultative Body has the following functions: ${ }^{15}$

\footnotetext{
4 Peraturan Menteri Dalam Negeri Nomor. 111/2014, Bab III, Bagian Kedua, Paragraf 2 Penyusunan Peraturan Desa oleh BPD.

15 Lihat Bab II Pasal 3 Peraturan Daerah Kabupaten Kuningan Nomor 17 Tahun 2006 tentang Badan Permusyawaratan Desa.
} 
1) Legislation Function, the legislative function carried out by BPD Sukaharja refers to the existing regulations. Kuningan District Regulation Number 17 of 2006 concerning the Village Consultative Body declares that BPD has the function of village regulations making together with the Village Head. Besides, BPD has a function to accommodate and convey community aspirations. Together with the Village Head, BPD formulates and establishes village regulations.

2) Supervision Function, the supervision on the implementation of village administration is one of the most important reasons why BPD needs to be formed. Supervision done by BPD on the implementation of Sukaharja village administration led by the Village Head is the task of BPD. The supervision efforts are intended to reduce the existence of irregularities in village authority and finance on the implementation of village administration.

3) Aspiration function, this aspiration function is the delivery of aspirations by community to BPD that can be done both individually and in groups by expressing directly to BPD members in their neighborhood (RW).

Meanwhile, the effectiveness of the Consultative Body of Sukaharja Village, Kuningan District, in implementing legislative function can be seen in the following table.

Table 1. The Effectiveness of Village Regulations Making

\begin{tabular}{|cc|}
\hline Year & Total \\
\hline 2010 & 4 village regulations \\
\hline 2011 & 2 village regulations \\
\hline 2012 & 1 village regulations \\
\hline 2013 & 4 village regulations \\
\hline 2014 & 2 village regulations \\
\hline 2015 & 3 village regulations \\
\hline Source: Village Secretariat of Sukaharja
\end{tabular}

\section{CONCLUSION}

From the discussion above, the authors draw the following conclusions:

a. Normatively, the establishment of village regulations in Sukaharja village is not running properly, and in its implementation, the establishment of village regulation in Sukaharja has not fully contained the principles of good regulations making based on Law Number 12 of 2011 concerning Establishment of Legislation. In its process, there are some stages which are not implemented by both village head and BPD so that the regulation is less effective for the society.

b. The Village Consultative Body has three main functions, namely legislation, supervision, and aspiration. Here, the Village Consultative Body is still less effective in implementing those three functions, especially the legislative function. It can be seen from the period of 2010-2015 in which the legal products produced by the BPD are very low, whereas there are many provisions that should have a legal umbrella in order to create legal certainty for the society. This situation happens because there is a lack of human resources in forming the village regulation draft, and the village government does not understand what the contents of the village regulations that should have a legal umbrella in village regulations making.

\section{SUGGESTION}

The suggestions that can be proposed concerning the effectiveness of implementing legislative function are:

a. Synergy between BPD and village head is needed as a good working partner in order to create good governance, especially in making legal products in the form of village regulations which are efficient for the society.

b. Training on legal drafting or drafting a good law and regulation is needed. In this case, we can request training from the competent, whether from campus academicians or from the district government through the government law firm.

\section{REFERENCES}

Bagir Manan (2005) Menyongsong Fajar Otonomi Daerah, Yogyakarta : Pusat Studi Hukum (PSH) Fakultas Hukum UII Yogyakarta.

Erga Yuhandra (2016). Kewenangan BPD (Badan Permusyawaratan Desa) Dalam Menjalankan Fungsi Legislasi (Sebuah Telaah Sosiologis Proses Pembentukan Perdes Di Desa Karamatwangi Kec. Garawangi Kab. Kuningan). UNIFIKASI: Jurnal Ilmu Hukum. 3(2). DOI: https://doi.org/10.25134/unifikasi. v3i2.410

Dirgantara Dani Putra (2009). Hubungan dan Peran Serta Badan Permusyawaratan 
Desa (BPD) dan Pemerintahan Desa Dalam Penyelenggaraan Pemerintahan Desa, Skripsi Universitas Sebelas Maret Surakarta, Surakarta.

E.B. Sitorus, dkk (2007). Naskah Akademik Rancangan Undang-Undang tentang Pemerintahan Desa, DEPDAGRI, Jakarta.

H.M. Hadin Muhjad \& Nunuk Nuswardani (2012). Penelitian Hukum Indonesia Kontemporer, Genta Publishing, Yogyakarta.

Jimly Asshiddiqie (2011). Pengantar Ilmu Hukum Tata Negara, Rajawali Press, Jakarta.

Jimly Asshiddiqie (2009) Komentar Atas Undang-Undang Dasar Negara Republik Indonesia Tahun 1945, Sinar Grafika, Jakarta.

Miriam Budiardjo (2010). Dasar-Dasar Ilmu Politik, PT Gramedia Pustaka, Utama, Jakarta.

M. Firmanhadi (2013). Hubungan Fungsional Antara Pemerintah Desa dengan BPD dalam Menjalankan Pelaksanaan Pemerintahan Desa Berdasarkan Undang-Undang Nomor 32 Tahun 2004 tentang Pemerintahan Daerah, Jurnal Ilmiah Fakultas Hukum Universitas Mataram.

Saldi Isra, Pergeseran Fungsi Legislasi (Menguatnya Model Legislasi Parlementer Dalam Sistem Presidensial Indonesia, PT Rajagrafindo Persada, Jakarta, 2010.

Tarsim dan Erga Yuhandra (2018). Implementasi Kewenangan Badan Permusyawaratan Desa (Bpd) Dalam Menjalankan Fungsi Pengawasan Terhadap Pemerintah Desa (Studi Di Kabupaten Kuningan), UNIFIKASI: Jurnal Ilmu Hukum. 5(1). DOI: https://doi.org/10.25134/unifikasi.v5i1.7 $\underline{59}$

Miriam Budiardjo (2010). Dasar-Dasar Ilmu Politik, PT Gramedia Pustaka, Utama, Jakarta, 2010.

Yamin, M. (1971) Naskah Persiapan UndangUndang Dasar 1945, Penerbit Siguntang, Jakarta, 1971, pp. 100. see Ni'matul Huda, Hukum Tata Negara Indonesia- Edisi 